\title{
PERBAIKAN KOMPETENSI MENGAJAR GURU MELALUI SUPERVISI KEPALA SEKOLAH DI MAN 1 MEDAN T.A. 2018/2019
}

\author{
Maysaroh \\ MAN 1 Medan
}

\begin{abstract}
Abstrak
Rancangan penelitian bentuk tindakan sekolah dengan memakai tindakan awal dan dua siklus selama tiga bulan, yang dimulai pada bulan Agustus sampai bulan Oktober 2018. Tujuan penelitian adalah 1) mengetahui tingkat prestasi dalam pelaksanaan tugas mengajar 2) mengetahui peningkatan prestasi kerja guru melalui supervisi objek penelitian guru MAN 1 Medan yang berstatus guru tidak tetap dengan masa kerja antara 1 s.d 3 tahun. Instrumen penelitian menggunakan observasi, studi dokumen dan dialog. Pada identifikasi masalah prestasi kerja kategori kurang pada dua indikator yang diteliti. Setelah dilakukan perbaikan pada siklus pertama dan kedua dapat diperoleh perbaikan prestasi dengan rincian sebagai berikut : 1) Indikator RPP diperoleh kategori baik 60\%, cukup 40\%. 2) Indikator 2 penyajian materi diperoleh kategori baik 70\% cukup 30\%, yang kurang 0\%. Memperhatikan hasil siklus 1 dan 2 dapat disimpulkan bahwa prestasi guru dapat diperbaiki melalui tindakan supervisi.
\end{abstract}

\section{Kata Kunci : Kompetensi Mengajar, Supervisi Kepala Sekolah}

\section{PENDAHULUAN}

Keberhasilan kerja guru dipengaruhi oleh peran kepala sekolah sebagai pimpinan, karena pada kemampuan kepala sekolah dalam mengkoordinasi, mengorganisasi semua komponen dengan baik, akan menimbulkan semangat dan sistematisnya sistem kerja organisasi. Hal ini merupakan kemampuan pimpinan dalam memandang bawahannya atau yang dipimpinnya. Sebagaimana dijelaskan oleh Teryy $(1960 ; 59)$ dalam bukunya "Prinsip-prinsip manajemen" mendefenisikan "k" sebagai kemampuan mengarahkan pengikut-pengikutnya untuk bekerjasama dengan kepercayaan serta tekun mengerjakan tugas-tugas yang diberikan pimpinan mereka.

Kepala sekolah yang mengarahkan bawahannya juga berperan sebagai pengawas, sehingga tidak terjadi miskomunikasi yang menyebabkan munculnya pernyataan bahwa kepala sekolah hanya dapat memerintah dan tidak ada tindak lanjut dari apa yang ia perintah. Hal ini menunjukkan fungsi pengawas belum dilaksanakan secara baik. Menurut Nasution (1996:1) pengawas berfungsi mengawas, dan membantu serta membimbing untuk memecahkan masalah-masalah pendidikan yang dihadapi oleh kepala sekolah, guru siswa maupun personel lainnya. Bantuan memecahkan masalahmasalah dalam suatu pekerjaan itulah yang disebut supervisi.

Supervisi dijelaskan Purwanto (1998 : 76) adalah suatu aktivitas pembinaan yang direncanakan untuk memantau para guru dan pegawai sekolah pada hakekatnya bukan hanya selaku administrator 
tetapi mengoptimalkan berbagai upaya untuk menciptakan suatu kondisi yang terencana secara sistematis dalam melakukan proses pendidikan.

Sejalan dengan itu Sahertian (1992:84) mengemukakan bahwa kepala sekolah memiliki tanggung jawab luar dalam memberhasilkan proses belajar mengajar, kepala sekolah sebagai supervisor mempunyai tugas membantu guru-guru memperbaiki situasi belajar mengajar dalam arti luas.

Supervisi pendidikan merupakan upaya yang terpaut erat dengan kegiatan administrasi pendidikan. Supervisi akan terlaksana dengan baik, apabila supervisor memahami dan menguasai seluk beluk administrasi pendidikan. Substansi supervisi berkenaan dengan kurikulum, perbaikan proses belajar-mengajar dan peningkatan profesional guru-guru dan personal sekolah lainnya. Dengan ketiga sasaran tersebut, diharapkan proses pendidikan terlaksana dengan efektif dan efisien lalu pada akhirnya kualitas pendidikan akan dapat dicapai lebih baik.

\section{Pengertian Supervisi}

Menurut Arikunto, (1993:153) istilah "supervisi" baru muncul kurang lebih dua dasawarsa terakhir ini. Dahulu istilah ini banyak digunakan di sekolah adalah "pengawas", penilik atau "pemeriksaan". Kegiatan supervisi melengkapi fungsi-fungsi administrasi yang ada di sekolah sebagai fungsi terakhir, yaitu penilaian semua kegiatan dalam pencapaian tujuan. Istilah pengawasan ini juga disebut "inspeksi" karena memiliki tujuan, yaitu mengawasi, mencari kekurangan atau kesalahan orangorang dalam melaksanakan tugasnya.

"Supervisi" yang muncul belakangan, yaitu yang menunjukkan pekerjaan pengawasan tetapi sifatnya lebih "human" (manusiawi). Tujuan utama dari pelaksanaan supervisi ini bukan mencari-cari kesalahan atau kekurangan, tetapi lebih bersifat pembinaan, agar pekerjaan yang menjadi sasaran supervisi dapat diketahui kekurangannya lalu tugas dari supervisor memperbaikinya, agar dapat ditingkatkan kualitas pekerjaan tersebut.

\section{Prestasi Kerja Guru}

Prestasi biasa diartikan sebagai peningkatan kualitas dalam suatu pekerjaan atau permainan, bisa juga peningkatan kecerdasan atau dalam istilah Purwanto (1998 : 102) suatu proses menimbulkan terjadinya suatu perubahan atau pembaharuan dalam tingkah laku atau kecakapan.

\section{Prestasi Kerja Guru}

Prestasi biasa diartikan sebagai peningkatan kualitas dalam suatu pekerjaan atau permainan, bisa juga peningkatan kecerdasan atau dalam istilah Purwanto (1998:102) suatu proses menimbulkan terjadinya suatu perubahan atau pembaharuan dalam tingkah laku atau kecakapan.

Gibson (1989), mengartikan prestasi kerja dengan sebutan hasil kerja yang diinginkan dari pelaku. Menurut Timpe (1993), mengartikan prestasi kerja sebagai penilaian terhadap tingkat kerja yang 
dicapai seseorang. Dapat pula dikatakan prestasi kerja sebagai keberhasilan seseorang dalam bekerja sesuai dengan kemampuan.

Dari beberapa pengertian di atas jika dihubungkan dengan prestasi kerja guru, dapat dikatakan bahwa prestasi kerja guru ini berhubungan dengan perilaku guru yaitu berbagai aktivitas guru dalam proses instruksional yang berkaitan dengan tanggung jawab dan tugas guru.

Jika diperhatikan dengan seksama bahwa tugas dan tanggung jawab guru itu sangat kompleks, tidak dapat dikaji secara parsial, oleh karenanya tugas guru yang mengutamakan peningkatan kualitas pendidikan tidak semudah membalikan telapak tangan. Sebagaimana tugas guru yang dijelaskan oleh Darmodiharjo (1989) bahwa :

a. Tugas profesional, yaitu tugas yang berhubungan dengan profesinya, meliputi tugas-tugas mendidik untuk mengembangkan kepribadian siswa, mengajar, untuk mengembangkan kemampuan berpikir, dan melatih, untuk mengembangkan keterampilan siswa.

b. Tugas manusiawi (human responsibility) yaitu tugas sebagai manusia dalam merealisasikan seluruh potensi yang dimilikinya, melakukan auto-identifikasi dan auto pengertian untuk dapat menampakkan dirinya dalam keseluruhan kemanusiaan. Dalam konteks ini guru berfungsi sebagai orang tua kedua.

c. Tugas kemasyarakatan (civic mission) yaitu sebagai anggota masyarakat dan warga negara yang bertugas membimbing siswa menjadi warga negara yang baik, sesuai dengan Pancasila, UndangUndang Dasar 1945 dan GBHN. Fungsi dalam hal ini sebagai pencipta masa depan.

Dengan tugas guru yang begitu kompleks, membuat seorang guru tersugesti untuk lebih meningkatkan kompetensi profesionalnya dalam dunia pendidikan. Salah satu dasarnya, seorang guru itu juga memiliki kemampuan dan memaknai peranan guru dalam dunia pendidikan. Menurut Soedijarto (1993), peranan guru dalam proses pembelajaran adalah :

a. Menguasai materi pelajaran secara mantap.

b. Menguasai dan dapat merencanakan berbagai model pengajaran yang relevan dengan bahan pelajaran pelajar dan tujuan pendidikan.

c. Menguasai dan dapat menggunakan/mengembangkan berbagai jenis dan bentuk evaluasi kemampuan belajar.

d. Mengenal karakteristik anak didiknya baik sebagai pelajar maupun sebagai manusia yang sedang menuju kedewasaannya.

e. Memahami kedudukan dan peranan pendidikan sekolah dalam keseluruhan proses pembangunan masyarakat seluruhnya dan manusia seutuhnya. 
Pengertian perilaku guru adalah berbagai aktivitas guru yang berhubungan dengan hal-hal yang harus dikerjakan, terutama aktivitas-aktivitas yang terkait dengan bimbingan dan arahan dalam pembelajaran.

Arikunto (1990:40) menjelaskan bahwa prestasi kerja guru dipengaruhi oleh berbagai faktor, secara global faktor-faktor yang mempengaruhi tersebut adalah faktor internal dan eksternal. Faktor internal terdiri dari sikap, minat, intelegensi, motivasi dan kepribadian. Sedangkan faktor eksternal menyangkut sarana dan prasarana, insentif (gaji), suasana kerja dan lingkungan kerja.

\section{METODOLOGI PENELITIAN}

\section{Lokasi Penelitian}

Objek penelitian ditetapkan penulis pada MAN 1 Medan yang merupakan sekolah binaan peneliti (kepala sekolah) dalam pelaksanaan tugas kepengawasan. Sebagai objek adalah guru-guru mata pelajaran yang terdiri dari berbagai latar belakang pendidikan dan bidang spesialisasi jurusan sebanyak 10 orang. Beberapa pertimbangan penulis menetapkan lokasi penelitian dan objeknya adalah 1) kemudahan untuk melakukan koordinasi tindakan yang diharapkan 2) pemahaman tentang berbagai kesulitan guru melakukan peningkatan prestasi kerja di sekolah.

\section{Perencanaan Tindakan}

Penelitian yang dilakukan bentuk penelitian tindakan kepengawasan pada aspek akademis dengan memakai dua siklus, setiap siklus akan menyempurnakan indikator penyempurnaan tugas pokok guru dalam mengajar.

\section{Pelaksanaan Tindakan}

1. Perencanaan

Peneliti menyiapkan beberapa keperluan yang mendukung terhadap kesempurnaan tindakan berupa jadwal, kesediaan kepada sekolah dan guru, kelengkapan alat penelitian tindakan dan peralatan pendukung. Kelengkapan dan hasil yang dicapai peneliti pada aspek perencanaan akan dijadikan dasar dalam pelaksanaan setiap siklus.

2. Pelaksanaan

Temuan tindakan awal yang diperoleh terhadap kesulitan prestasi kerja guru mengajar diharapkan guru mata pelajaran dapat menetapkan urutan-urutan kesulitan melakukan prestasi kerja dalam mengajar. Dengan dasar itu peneliti dan guru bersama-sama melakukan tindakan perbaikan dan peningkatan hasil kerja guru mengajar.

3. Observasi

Aksi yang dilakukan guru dalam pemahaman kedua indikator peningkatan prestasi kerja guru akan dinilai beberapa ketercapaian yang telah baik dan hambatan-hambatan yang dialami dalam mencapai indikator yang telah ditetapkan dalam penelitian. 


\section{Refleksi}

Keberhasilan dan kesulitan yang diperoleh para guru mata pelajaran dijadikan acuan pada siklus berikutnya. Seluruh pencapaian data akan diinterprestasikan lebih dahulu dengan cermat oleh peneliti kemudian diberikan tindakan-tindakan yang sesuai guna perbaikan dan penyempurnaan dalam mencapai indikator penelitian.

\section{HASIL PENELITIAN}

Penelitian diawali dengan tindakan awal untuk mengetahui tingkat prestasi guru dalam melaksanakan tugas pokoknya sehari-hari. Setelah selesai tindakan awal dapat digambarkan bahwa kelemahan yang menonjol dalam pengelolaan tugas-tugas guru adalah 1) Kemampuan merancang program pembelajaran dengan tingkat keberhasilan rendah, 2) kemampuan dan eksistensi menerapkan rancang pembelajaran yang tergolong kurang.

Untuk mendapatkan tingkat keberhasilan tersebut peneliti melakukan dengan observasi, studi dokumen dan wawancara terhadap dokumen pembelajaran guru mata pelajaran.

Kemampuan/prestasi guru menyusun rancangan program pembelajaran sesuai bidang tugas masing-masing dengan data seperti tabel 1.

Tabel 1. Hasil Siklus I, Prestasi Guru Menyusun Rancangan Pembelajaran

\begin{tabular}{|l|c|c|c|c|}
\hline No & Kemampuan & Kriteria & F & Prestasi \\
\hline 1. & $85-100$ & Sangat baik & 0 & 00,00 \\
\hline 2. & $75-84$ & Baik & 0 & 00,00 \\
\hline 3. & $65-74$ & Cukup & 4 & 40,00 \\
\hline 4. & $55-64$ & Kurang & 5 & 50,00 \\
\hline 5. & $0-54 \quad$ Sangat kurang & 1 & 10,00 \\
\hline \multicolumn{2}{|c|}{ Jumlah } & 10 & 100,00 \\
\hline
\end{tabular}

Dengan memperhatikan tabel 1 dapat disimpulkan bahwa untuk indikator satu diperlukan tindakan penyempurnaan kemampuan guru mata pelajaran melalui : a) penjelasan/dialog, b) pemberian contoh, c) penugasan-penugasan. Adapun rincian prestasi kemampuan adalah : kriteria cukup 40\%, dan kategori kurang 50\%. Hal ini menggambarkan diperlukan peningkatan prestasi guru.

Tabel 2. Siklus I Pada Indikator, Prestasi Guru Mengajar

\begin{tabular}{|l|c|c|c|c|}
\hline No & Kemampuan & Kriteria & F & Prestasi \\
\hline 1. & $85-100$ & Sangat baik & 0 & 00,00 \\
\hline 2. & $75-84$ & Baik & 0 & 00,00 \\
\hline 3. & $65-74$ & Cukup & 7 & 70,00 \\
\hline 4. & $55-64$ & Kurang & 3 & 30,00 \\
\hline 5. & $0-54 \quad$ Sangat kurang & 0 & 00,00 \\
\hline \multicolumn{2}{|c|}{ Jumlah } & 10 & 100,00 \\
\hline
\end{tabular}

Penyebaran data menunjukkan cukup 70\%, kurang 30\%. Bila dihubungkan dengan indikator 1 dapat disimpulkan terdapat korelasi bahwa kemampuan mengajar guru lemah. 
Berdasarkan data prestasi guru MAN 1 Medan pada Tabel 1 dan 2 peneliti melakukan tindakan supervisi (pembinaan) sebagai tindakan perbaikan dan penyempurnaan dengan mengulang pengembangan kedua indikator tersebut.

Tabel 3. Siklus II Prestasi Guru, Indikator : Penyusunan Program Pembelajaran Guru

\begin{tabular}{|l|c|c|c|c|}
\hline No & Kemampuan & Kriteria & F & Prestasi \\
\hline 1. & $85-100$ & Sangat baik & 2 & 20,00 \\
\hline 2. & $75-84$ & Baik & 4 & 40,00 \\
\hline 3. & $65-74$ & Cukup & 4 & 40,00 \\
\hline 4. & $55-64$ & Kurang & 0 & 00,00 \\
\hline 5. & $0-54$ & Sangat kurang & 0 & 00,00 \\
\hline \multicolumn{2}{|c|}{ Jumlah } & 10 & 100,00 \\
\hline
\end{tabular}

Penyebaran data menunjukkan terjadi perbaikan prestasi (kemampuan) guru dalam memahami indikator 1 dengan rincian $60 \%$ baik, $40 \%$ cukup dan kriteria tidak $0 \%$.

Tabel 4. Siklus II Prestasi Guru, Indikator : Prestasi Guru Mengajar

\begin{tabular}{|l|c|c|c|c|}
\hline No & Kemampuan & Kriteria & F & Prestasi \\
\hline 1. & $85-100$ & Sangat baik & 3 & 30,00 \\
\hline 2. & $75-84$ & Baik & 4 & 40,00 \\
\hline 3. & $65-74$ & Cukup & 3 & 30,00 \\
\hline 4. & $55-64$ & Kurang & 0 & 00,00 \\
\hline 5. & $0-54 \quad$ Sangat kurang & 0 & 00,00 \\
\hline \multicolumn{2}{|c|}{ Jumlah } & 10 & 100,00 \\
\hline
\end{tabular}

Penyebaran data pada tabel 5 dapat tergambar bahwa prestasi kerja guru dalam menyampaikan materi pembelajaran disimpulkan kriteria baik 70\%, cukup 30\%, kurang $0 \%$. Cerminkan prestasi guru MAN 1 Medan terhadap indikator satu dan dua mengalami perbaikan.

\section{PEMBAHASAN}

Keberhasilan kinerja guru yang baik pada setiap suatu pendidikan pada saat ini tergolong belum dapat dibanggakan, hal ini terbukti dengan mutu pendidikan secara nasional. Memperhatikan temuan penelitian pada MAN 1 Medan tampaknya dapat dijadikan sebagai ilustrasi kondisi satuan pendidikan kita saat ini. Berdasarkan hasil observasi dan wawancara terhadap guru di sekolah dapat diketahui faktor penyebabnya adalah 1) jaminan kesejahteraan guru yang rendah 2) kebiasaan guru melakukan tugas mengajar di beberapa sekolah setiap minggu 3) dukungan manajemen/ yayasan sekolah tergolong rendah.

Pada siklus satu menggambar terdapat prestasi yang kurang dengan persentasi $50 \%$ pada indikator 1 dan 30\% pada indikator 2, kemudian peneliti menganalisi kesulitan dan hambatan yang dialami guru. Peneliti melakukan perbaikan prestasi kerja guru, menyempurnakan format menyusun rancangan pembelajaran dan menampilkan pola pembelajaran yang baik. 
Setelah dilakukan peran Supervisi Kepala Sekolah terhadap indikator yang telah ditetapkan lebih awal yaitu :

a. Penyusunan program pembelajaran guru

b. Prestasi guru mengajar di kelas.

Pada siklus satu kedua indikator tersebut masih berada pada perolehan hasil yang kurang dengan persentasi sangat kurang, kurang dan cukup mencapai rata-rata 35\%. Sedangkan kriteria baik dan sangat baik belum tercapai. Untuk penyempurnaan prestasi mengajar guru pada kemampuan menyusun program dan mengajar dilakukan pengawas perbaikan-perbaikan lebih lanjut pada Siklus II. Adapun perbaikan yang diperoleh pada indikator penyusunan pembelajaran dengan rata-rata persentasi pada kategori cukup, baik dan amat baik mencapai 33,01\%, sedangkan prestasi menyajikan pembelajaran mengalami perbaikan pada kategori cukup, baik dan amat baik dengan rata-rata mencapai $33,01 \%$.

Berdasarkan perolehan hasil pada siklus I dan II dapat tercermin bahwa prestasi guru dalam bidang tugasnya dapat ditingkatkan melalui peran Supervisi Kepala Sekolah.

\section{KESIMPULAN}

Kemampuan prestasi guru mata pelajaran yang terbatas dalam menyusun rancangan pembelajaran berupa silabus, RPP dan alat evaluasi ternyata masing-masing guru mempunyai kesulitan dalam melakukan penampilan penyajian. Untuk menghindari seperti ini kepala sekolah dan pengawas mutlak melakukan supervisi (pembinaan) terhadap guru. Melalui supervisi dapat membantu dan meningkatkan prestasi kerja guru mata pelajaran.

\section{DAFTAR PUSTAKA}

Departemen P dan K, (1979), Administrasi Sekolah, Proyek Pengadaan Buku SPG, Jakarta.

Purwanto, M. Ngalim (1998), Administrasi dan Supervisi Pendidikan, Bandung : Remaja Rokdakarya.

Sahertian Piat A, (1994) Profil Pendidikan Profesional, Yogyakarta : Andi Offset.

Subroto, B. Suryo, (1984) Dimensi-dimensi Administrasi Pendidikan di Sekolah, Jakarta Bina Aksara.

Sutisna, Oteng (1983), Administrasi Pendidikan Dasar Teoritis Untuk Praktek Profesional, Bandung : Angkasa. 